\title{
An Investigation of a Relationship between Aggression and Wellbeing among Adolescents
}

\author{
Harshmeet Kaur \\ Department of Psychology, Panjab University, Chandigarh, India \\ E-Mail: harshmeetkaur8@gmail.com
}

\begin{abstract}
The study investigated the relationship between aggression and wellbeing among adolescents. A sample of 250 adolescents equally divided among males and females aged 1618 years were taken. Various self-report measures were administered, for example, aggression questionnaire by Buss and Perry (1992), satisfaction with life scale by Diener, Emmons, Larsen, and Griffin (1985), positive affect and negative affect acale by Watson, Clark, and Tellegen (1988), and psychological wellbeing scale by Ryff and Keyes (1995). Means and Standard deviations, $t$-ratios and Correlation Analysis were carried out. Findings indicated significant and inverse relationship between aggression and wellbeing. Significant gender differences emerged in physical aggression where males scored higher as compared to females.
\end{abstract}

Keywords: Aggression, Adolescents, Wellbeing

\section{INTRODUCTION}

World Health Organization (2016) has reported that youth violence has taken a stride among 10-29 year olds and peaks during late adolescence and early adulthood. Reviewing the findings of studies on teenage aggression in India, it has been found that aggression as well as intensity of aggression among Indian adolescents has increased over the years leading to severe physical, psychological, communal and economic consequences (Kumar, Bhilwar, Kapoor, Sharma, \& Parija, 2016). Aggression is defined as "a behavior with an intention to harm, hurt, or injure others (Bushman \& Huesmann, 2010).

\section{A. Forms of Aggression}

Aggression can take distinct forms which can range from physical fighting and bullying, emotional abuse, homicides, assaults to dating violence (WHO, 2016). Buss et al., (1992) identified four sub-traits of aggression: physical aggression, verbal aggression, anger, and hostility. Hostility, anger and aggression are related constructs and it is also termed as "anger-hostility-aggression" (Pérez-Nieto, Camunas, CanoVindel, Miguel-Tobal, \& Iruarrizaga, 2000). Physical Aggression is intended to harm other person physically (such as hitting, kicking, biting, stabbing, shooting etc.). Verbal Aggression is intended to harm another person by using verbal language (such as yelling, screaming, name calling etc.).Verbal Aggression can be direct or indirect (Bushman et al., 2010). Relational Aggression is intended to harm other person's social network. This type of aggression is also known as Social Aggression. Direct Aggression is directed towards the physically present victim. Indirect
Aggression is intended to harm another person indirectly. Cold Aggression is involves a deliberate plan to harm the target person (as discussed in Warburton \& Anderson, 2015). The term violence is often used synonymously with aggression. However, social psychologists have regarded violence as a sub-type of aggression to avoid confusion.

\section{B. Gender Differences}

Majority of the studies have indicated the differences in gender in relation to preferred styles of aggression. Findings have indicated that males have consistently been found to be more physically aggressive as compared to women (Buss $e t$ al., 1992; Dutt et al., 2013; Sharma \& Marimathu, 2014). Similar results were reported in studies conducted among adolescents (Smith-Khuri et al., 2004). Studies related to gender differences in verbal aggression showed a mixed pattern and small size effects (Buss et al., 1992).

\section{Factors Influencing Aggression}

World Health Organization Youth Violence Fact Sheet (2016) has indicated various possible risk factors which put youth to practice violence, for example, risk factors within individual (such as destructive behavior/ behavioral disorders, drugs/alcohol abuse, failures in school, family violence etc.), risk factors within close relationships (such as inadequate parental supervision of children, parental bonding, parental depression, antisocial peer groups), risk factors within community (such as living in poverty/ high income, weak implementation of government, education and social laws/ policies).

Psychophysiological studies have indicated that persistent and impulsive aggression is linked with low baseline heart rate, increased autonomic reactivity to stressful stimuli, increased EEG slow wave activity, decreased P300 brain potential response, disruptions in affective regulatory systems i.e. front-cortical and limbic brain regions (Patrick, 2008; Sterzer \& Stadler, 2009). Genetic studies have indicated that Monoamine Oxidase A gene (MAOA) polymorphism and $5-\mathrm{Ht}$ serotonin transporter gene are two widely studied genetic markers that predispose one towards aggression and also interact with childhood maltreatment and adversity (Kim-Cohen et al., 2006).

Violent behavior in adolescence is linked with a history of childhood aggression, disruptive behavior patterns, conduct 
disorders and juvenile delinquency in early childhood (Laub \& Sampson, 1993).Early aggression is linked with continuity in antisocial behavior leading to crime (Ttofi, Farrington, Lösel, \& Loeber, 2011). Studies have indicated that child maltreatment in the form of physical abuse, sexual abuse, emotional abuse and neglect of children is linked with the occurrence of antisocial and violent behavior in childhood and adolescence (Smith \& Thornberry, 1995; Maxfield \& Widom, 1996; Fang \& Corso, 2007). Negative personality traits are associated with aggression (Barlett \& Anderson, 2012).

Peer pressure plays an important role in adolescent aggression. Adolescent aggressive behavior usually occurs in groups or gangs displaying risky behaviors (Lopez \& Emmer, 2002). Negative parent-child relationship may lead to non-compliance behavior. Estévez, Moreno, Jiménez, and Musitu (2013) indicated that lack of protection from adult figures is linked with adolescent aggression. At school, poor relationship of the child with teacher is a risk factor for developing aggression (Valadez, 2008). Evidence has indicated that insecure attachment styles during early years contribute to aggression during adolescence (Bowlby, 1988). Children with parents suffering from depression and alcohol abuse have an increased risk for developing antisocial behavior (Hill \& Muka, 1996; Pemberton et al., 2010).

Other established risk factors like low maternal education, poverty, harsh, abusive, or lax parenting have been linked with violence (Hunter, Jain, Sadowski, \& Sanhueza, 2000; Blum, Ireland, \& Blum, 2003; Simons-Mortons, Hartos, \& Haynie, 2004). Psychological conditions like hyperactivity, impulsivity, negative life events, concentration problems, restlessness, risk taking, low self-control, low-self-esteem, low happiness levels, sensation seeking, childhood attention deficit-hyperactivity disorders increase the chances of manifesting aggressive behavior and violence in youth (Krakowski, 2003; Puskar, Bernardo, Hailey, \& Hetager Stark, 2008; Mofitt et al., 2011; Bernat, Oakes, Pettingell, \& Resnick, 2012; Lee, Gil, Yoo, \& Kim, 2012; Penton-Voak, Thomas, Gage, McMurran, McDonald, \& Munafo, 2013). Studies have indicated that depression and academic stress as the strong causes of aggression among adolescents (Kim \& Lee, 2008; Jin, Park, \& Bae, 2011).

\section{Theories related to aggression}

Dollard, Doob, Miller, Mowrer, and Sears (1939) proposed frustration-aggression hypothesis. The theory was based on the following assumptions:

1. Aggressive behavior stems from the existence of frustration.

2. Frustration always leads to some form of aggression. Miller (1941) revised the theory and explained that frustration stimulates number of other aggressive and nonaggressive behaviors like escaping etc. and not only aggression. Research evidence has supported that aggression can be learned through conditioning processes (positive reinforcement, negative reinforcement, stimulus generalization) (Patterson, Littman, \& Bricker, 1967). Classic 'Bobo Doll' experiments conducted by Bandura and associates with children indicated that aggressive behavior was learnt by children by observing an actor hitting the doll in several ways (Bandura, Ross, \& Ross, 1963). Exposure to violent pornography has been found to be associated with negative outcomes (Malamuth \& Brown, 1994). Huesmann (1982) theorized that "scripts define situations in a way that a person first chooses a script to represent the situation and then assumes a role in the script. Scripts guide behavior in a way that is well-rehearsed and retrieved at some later time (Abelson, 1981; Anderson et al., 2002). For example, if an adolescent has witnessed several instances of aggressive behavior will be likely to have an accessible script that can be generalized across many situations.

A unified model was proposed by Anderson et al., (2002) i.e. general aggression model which has integrated existing major theories of aggression. The model stated that "aggression involves person responding to an aggressive situation. Person and situation variables influence the person's present internal state (cognitions, affects, and physiological arousal) which activate knowledge structures (which include affect) and the amount of arousal. A person may act on impulsively or thoughtfully depending on the appraisal process. The resulting behavior will feedback into the immediate situation and also influence the person's personality" (Anderson et al., 2002; Warburton et al., 2015). Studies have indicated that aggression in childhood and adolescence deteriorates physical and psychological wellbeing (Boynton-Jarrett, Ryan, Berkman, \& Wright, 2008; Haynie, Petts, Maimon, \& Piquero, 2009; Skapinakis et al., 2011; Swahn, Bossarte, Palmier, Yao, \& Dulmen, 2013).

\section{E. Wellbeing}

Wellbeing is a multifaceted construct i.e. it is concerned with two distinct yet overlapping paradigms of wellbeing i.e. the hedonic and the eudaimonic viewpoints (Ryan \& Deci, 2001). The present investigation has taken both viewpoints i.e. hedonic and eudaimonic wellbeing.

\section{F. The Hedonic Viewpoint}

The viewpoint has been expressed by Greek philosophers as bodily pleasures, positive emotional states and enjoyment (Ryan et al., 2001). Many Indian thinkers held the view that pleasure is a desirable feeling which rests on gratification or satisfaction (Prasastapada, 400 CE, Sridhara, $1000 \mathrm{CE}$, Kesavamisra, $1300 \mathrm{CE}$, Annambhatta, $1700 \mathrm{CE}$, to name a few). Similarly, pain has been regarded by many Indian thinkers as an undesirable feeling when one encounters undesirable object or event and feels stuck. Kahneman et al., (1999) defined hedonic psychology as the study of "what makes experiences and life pleasant and unpleasant" (p. 9). Diener (2000) clearly indicated that subjective wellbeing has three components: satisfaction with life (cognitive 
part), positive affect and absence of negative affect (affective apart). Positive affect refers to "frequency and intensity of pleasant emotions". Negative affect refers to "frequency and intensity of unpleasant emotions" (Diener et al., 1999). Life satisfaction has been referred to as "cognitive judgment concerning how satisfied a person is with his life" (Diener et al., 1999). High levels of wellbeing are associated with frequent occurrences of positive experiences and less frequent occurrences of negative experiences (Diener et al., 1999).

\section{G. The Eudaimonic Viewpoint}

The eudaimonic concept of well-being has been defined as "living in accordance with one's true self" by Waterman (1993). The followers of eudaimonic psychology held that true happiness is attained in meaningful life. Ryff and Singer (1998) defined psychological wellbeing "as the striving for perfection which indicates the realization of one's true potential and not just the attainment of pleasure". Ryff and Keyes (1995) proposed six essential components of psychological wellbeing i.e. autonomy, environmental mastery, personal growth, positive relations with others, purpose in life and self-acceptance.

The concept of wellbeing in Indian philosophy refers to wellbeing at physical, psychological as well as spiritual levels which is parallel to Western models of wellbeing i.e. hedonic wellbeing and eudaimonic wellbeing (Singh, Junnarkar, \& Kaur, 2016).Both Western and Indian perspectives of wellbeing maintain that the umbrella term 'wellbeing' is connected with the concept of happiness, mental health, life satisfaction, and actualization of one's full potential. Researchers in the field of positive psychology in India have tried to relate well-being to traditional concepts such as Sat-chit-ananda (bliss), Koshas (self), Doshas (imbalance of mind, body and soul), Gunas (virtues), Vikaras (vices), Sakti (divine energy) and Anasakti (detachment). These concepts have been found in various religious texts and ancient texts on Ayurveda (Singh et al., 2016). Some of the newer models of wellbeing take into account the combined view of hedonic and psychological wellbeing. For example, Flourishing model (Keyes, 2002; 2005), Thriving model (Diener et al., 2010), PERMA model (Seligman, 2011).

\section{H. The Current Study}

While reviewing research papers, articles and databases like PubMed and Google Scholar, it has been found that although reporting of adolescent aggression is increasing but limited research evidence has been published studying the relationship between aggression, subjective wellbeing and psychological wellbeing among adolescents in India. Considering the above, study was conducted. Adolescence is marked by significant and rapid developmental changes which have been linked with increased stress, low levels of happiness and increased turbulent emotional experiences (Silvers et al., 2012).

\section{METHODS}

\section{A. Participants}

Data were drawn by obtaining a list of Government Model Senior Secondary Schools of Chandigarh. The total sample size taken was 250 adolescents aged 16-18 years which was equally divided among males and females. Informed consent was obtained from the subjects before they were enrolled in the study. All the interested subjects were administered self-reports measures in a booklet form in a group setting. Confidentiality was maintained. Proper standardized instructions were given to the subjects as specified in the manuals.

\section{B. Hypotheses}

1. Aggression will be negatively related to subjective wellbeing.

2. Aggression will be negatively related to psychological wellbeing.

3. Gender differences will be expected in Aggression.

\section{MEASURES}

\section{A. Aggression}

Aggression was measured using aggression questionnaire (Buss et al., 1992). It consists of 29 items. It has 4 subscales measuring Physical Aggression, Verbal Aggression, Anger and Hostility. The responses are given using a 5-point Likert type scale. The questionnaire demonstrates good psychometric properties with adolescent sample (Reyna, Lello, Sanchez, \& Brussino, 2011). In India, the scale has been used by various researchers like Shaheen et al., (2014), Singh (2016).

\section{B. The Satisfaction with Life Scale}

Cognitive component of subjective wellbeing was assessed using the scale devised by Diener et al., (1985). The scale consists of 5-items. The scale has favorable psychometric properties including high internal consistency and high temporal stability. It is suitable to be used with range of age-groups (Diener et al., 1985). The scale has been used with various age groups in Indian settings (Yadav, 2010).

\section{Positive Affect and Negative Affect Scale}

Affective component of wellbeing was assessed using positive affect and negative affect scale. It is a short measure devised by Watson et al., (1988). It has 20 items. There are 10 items for positive affect and 10 items for negative affect. The responses are given by using a 5-point Likert-type rating scale. The scale has good reliability and validity. The scale has been used with adolescents in Western and Indian settings (Yadav, 2010; Moreira et al., 2014). 


\section{Psychological Wellbeing Scale}

The scale has been developed by Ryff et al., (1995) to measure six dimensions of psychological wellbeing. The six dimensions measured by the scale are Autonomy, Environmental Mastery, Personal Growth, Positive Relations with Others, Purpose in Life, and SelfAcceptance.

A total of 6 measurement scales have been developed to assess psychological wellbeing. Each scale has been different in length of items. For the present study, 84-item scale has been used. There are 14 items for each dimension. The responses are given using a six-point format. The scale bears good psychometric properties. The scale has been used with adolescents in Indian setting (Yadav, 2010).

\section{E. Statistical Analyses}

Statistical analyses were carried out by using Statistical Product and Service Solutions (SPSS) Package. Means and Standard Deviations, $t$ ratios and Correlation Analysis were carried out.

\section{RESULTS}

Mean, standard deviation, and $t$-ratios depicting gender differences are reported in Table I. Correlation coefficients are reported in Table II and Table III.

TABLE I MEANS AND STANDARd DEVIaTIONS

\begin{tabular}{|c|c|c|c|c|}
\hline \multirow{2}{*}{ Variables } & Males $(\mathbf{n}=\mathbf{1 2 5})$ & Females $(\mathbf{n}=\mathbf{1 2 5})$ & \multirow{2}{*}{$\boldsymbol{t}$} & $\boldsymbol{p}$ \\
\cline { 2 - 4 } & Mean $(\mathrm{SD})$ & Mean $(\mathrm{SD})$ & & \\
\hline P-AGG & $\mathrm{M}=21.81(\mathrm{SD}=6.82)$ & $\mathrm{M}=17.86(\mathrm{SD}=6.72)$ & 4.61 & $0.01 * *$ \\
\hline V-AGG & $\mathrm{M}=14.84(\mathrm{SD}=4.59)$ & $\mathrm{M}=14.92(\mathrm{SD}=4.35)$ & 0.14 & 0.89 \\
\hline ANG & $\mathrm{M}=19.80(\mathrm{SD}=6.96)$ & $\mathrm{M}=20.39(\mathrm{SD}=6.85)$ & 0.68 & 0.50 \\
\hline HOS & $\mathrm{M}=20.83(\mathrm{SD}=7.03)$ & $\mathrm{M}=22.22(\mathrm{SD}=8.18)$ & 1.43 & 0.15 \\
\hline AGG & $\mathrm{M}=77.28(\mathrm{SD}=23.54)$ & $\mathrm{M}=75.39(\mathrm{SD}=22.41)$ & 0.65 & 0.52 \\
\hline \multicolumn{2}{|r|}{ Note: $\mathrm{P}-\mathrm{AGG}=$ Physical Aggression, V-AGG $=$ Verbal Aggression, }
\end{tabular}

$\mathrm{ANG}=$ Anger, $\mathrm{HOS}=$ Hostility, $\mathrm{AGG}=$ Overall Aggression

\section{A. Significant Gender Differences in Aggression}

Significant gender difference was found in physical 6.82) scored higher than females $(M=17.86, S D=6.72)$ in aggression sub-trait of aggression. Males $(M=21.81, S D=$ physical aggression, $t(248)=4.61, p \leq 0.01$.

Table it Pearson Product Moment Correlations Of Aggression And Subjective Wellbeing ( $\mathrm{N}=250)$

\begin{tabular}{|c|c|c|c|c|c|c|c|c|c|}
\hline Variables & PA & NA & SWL & SWB & P-AGG & V-AGG & ANG & HOS & AGG \\
\hline PA & 1 & $-.67^{* *}$ & $.81^{* *}$ & $.92^{* *}$ & $-.64^{* *}$ & $-.69^{* *}$ & $-.75^{* *}$ & $-.77^{* *}$ & $-.81^{* *}$ \\
\hline NA & & 1 & $-.70^{* *}$ & $-.88^{* *}$ & $.55^{* *}$ & $.65^{* *}$ & $.70^{* *}$ & $.72^{* *}$ & $.75^{* *}$ \\
\hline SWL & & & 1 & $.88^{* *}$ & $-.63^{* *}$ & $-.69^{* *}$ & $-.801^{* *}$ & $-.78^{* *}$ & $-.83^{* *}$ \\
\hline SWB & & & & 1 & $-.67^{* *}$ & $-.75^{* *}$ & $-.82^{* *}$ & $-.83^{* *}$ & $-.88^{* *}$ \\
\hline P-AGG & & & & & 1 & $.64^{* *}$ & $.64^{* *}$ & $.62^{* *}$ & $.83^{* *}$ \\
\hline V-AGG & & & & & 1 & $.76^{* *}$ & $.74^{* *}$ & $.86^{* *}$ \\
\hline ANG & & & & & & 1 & $.81^{* *}$ & $.91^{* *}$ \\
\hline HOS & & & & & & & 1 & $.91^{* *}$ \\
\hline AGG & & & & & & & 1 \\
\hline
\end{tabular}

$\mathrm{SWB}=$ Subjective Wellbeing, $\mathrm{P}-\mathrm{AGG}=$ Physical Aggression, $\mathrm{V}-\mathrm{AGG}=$ Verbal Aggression, $\mathrm{ANG}=$ Anger, $\mathrm{HOS}=$ Hostility, $\mathrm{AGG}=$ Overall Aggression

\section{B. Relationship between Aggression and Subjective} Wellbeing among Adolescents

A perusal of inter-correlation matrix (Table II, N=250) revealed significant negative correlations between aggression and subjective wellbeing. Significant negative correlation was found between physical aggression and subjective wellbeing $(\mathrm{r}=-0.67, p \leq 0.01)$, verbal aggression and subjective wellbeing $(\mathrm{r}=-0.75, p \leq 0.01)$, anger and subjective wellbeing $(\mathrm{r}=-0.82, p \leq 0.01)$, hostility and subjective wellbeing $(\mathrm{r}=-0.84, p \leq 0.01)$, overall aggression and subjective wellbeing $(\mathrm{r}=-0.88, p \leq 0.01)$.

\section{Relationship between Aggression and Psychological Wellbeing among Adolescents}

A perusal of inter-correlation matrix (Table III, N=250) revealed significant negative correlations between aggression and psychological wellbeing. 
Significant negative correlation was found between physical aggression and psychological wellbeing $(r=-0.64, p \leq$ $0.01)$, verbal aggression and psychological wellbeing $(\mathrm{r}=-$ $0.74, p \leq 0.01)$, anger and psychological wellbeing $(\mathrm{r}=-$ $0.83, p \leq 0.01)$, hostility and psychological wellbeing $(\mathrm{r}=-$ $0.79, p \leq 0.01)$, overall aggression and psychological wellbeing $(\mathrm{r}=-0.85, p \leq 0.01)$.

\section{DISCUSSION AND CONCLUSION}

We investigated the relationship between aggression and wellbeing among adolescents. Males scored higher in physical aggression as compared to females. Present finding has been supported by existing findings. Evidence published on aggressive behavior among children and adolescents in India, although limited, has indicated that physical aggression is a pressing issue among males (Dutt et al., 2013; Sharma \& Marimathu, 2014). Media has reported increase in destructive behaviors in India like slapping, hitting, eve-teasing, rape, shooting, truancy, road rage, use of weapons etc. more among boys.

A possible explanation behind the prevalence of physical aggression among adolescent boys comes from Bjorkqvist, Osterman, and Kaukiainen (1992) study in which they claimed that developmentally direct aggression strategies develop earlier as compared to indirect aggression strategies among boys. Indirect aggression strategies are dependent on certain level of maturation and social skills which boys develop later. Another reason could be that in Indian culture, girls suppress their aggression and are expected to be less overt. Hence, they resort to less physical aggression strategies or do not exhibit anger in overt way much often (Bjorkqvist, Lagerspetz, \& Kauhiainen, 1992; Murlidhar \& Shastri, 2016). Correlation analysis revealed significant and inverse relationship between aggression and subjective wellbeing.

Significant and inverse relationship was found between aggression and psychological wellbeing. Existing evidence has clearly indicated the repercussions of aggressive behavior on physical and psychological wellbeing outcomes. For example, Miller, Smith, Turner, Guijarro, and Halley (1996) conducted a meta-analytic study on hostility and physical health. The results suggested that hostility is an independent risk factor for coronary heart disease.

Musante and Trieber (2000) indicated that anger expression and anger suppression related to unhealthy lifestyle like lack of physical activity and high consumption of alcohol, cigarettes and caffeine among adolescents. Diong et al., (2005) examined the relationships between anger, stress, perceived social support, coping strategies and health.

Results indicated that high dispositional anger was found to be directly related to high levels of stress and low levels of perceived social support. It was indirectly related to greater use of avoidance coping. It was directly and indirectly related to low psychological wellbeing and high psychological distress. Mitrofan and Ciuluvică (2011) examined the relationship between difficulties with emotion regulation, aggression, and life satisfaction among high school students and undergraduates. The results indicated significant and negative correlation between anger, hostility and life satisfaction. Kaplan (2017) study indicated that subjective wellbeing is significantly and negatively correlated with hostility and overall emotional problems. According to Broaden and Build model, the purpose and influence of negative emotions such as anger is that they narrow one's thought-action repertoires which in turn produce negative effects on one's physical and mental health (Fredrickson, 2000). Present study and review of literature has suggested that aggression drains one's adaptive coping and thus, debilitates one's subjective and psychological wellbeing. It has a shadowing effect on one's effective emotion regulation strategies to deal with distressing situations.

Peace building workshops with a special emphasis on psychoeducation, emotional self-management, cognitive restructuring skills, interpersonal skills etc. should be conducted in school settings in order to sensitize schoolgoing children and building a sustainable future for them (McGuire, 2008). Social psychologists have begun to focus on human strengths as protective factors for reducing youth violence (Borum, Bartel, \& Forth, 2005).

Evidence has suggested that positive psychology based interventions are effective in enhancing subjective and psychological wellbeing and reducing negative symptoms (Sin \& Lyubomirsky, 2009; Tweed, Bhatt, Dooley, Spindler, \& Douglas, 2011).

Employing positive psychology based tools in therapeutic settings may have a significant effect on reducing aggression and inhibiting violence among youth. Given the rise of aggression among children and adolescents, earlyintervention programs based on enhancing social and emotional skills can be helpful in preventing aggression. Parents can be involved in certain sessions where they can be imparted short training on helping their adolescents.

\section{A. Limitations}

The study is limited in the form of a research design, sample chosen and measures undertaken. The current study has limited itself to study relationship between aggression and wellbeing. It is difficult to draw causal inferences i.e. whether aggression is leading to low wellbeing or viceversa. Sample is not nationally representative. We limited our data collection to one city in North India. Future research will focus on a much bigger representative sample and cross-national comparative research. We relied on selfreport measures for data collection.

Future research will benefit from using different approaches in addition to self-report measures such as observation method, parent-teacher reports and observations, 
experimental designs, intervention-based designs etc. Also, linking positive psychology and psychology of aggression may bring out some strength variables largely ignored in existing research literature. Such researches will help counsellors and psychotherapists in incorporating strengthbased interventions in anger management programs.

\section{B. Conflicts of Interest}

There is no conflict of interest.

\section{REFERENCES}

[1] Abelson, R. P. (1981). Psychological status of the script concept. American Psychologist, 36, 715-729. doi:10.1037/0003066X.36.7.715

[2] Anderson, C.A. (1997). Effects of violent movies and trait irritability on hostile feelings and aggressive thoughts. Aggressive Behavior, 23, 161- 78. doi.org/10.1002/(SICI)1098-2337(1997)23:3<161::AID$\mathrm{AB} 2>3.0 . \mathrm{CO} ; 2-\mathrm{P}$

[3] Bandura, A., Ross, D., \& Ross, S. A. (1963). Imitation of filmmediated aggressive models. The Journal of Abnormal and Social Psychology, 66(1), 3-11. doi: 10.1037/h0048687

[4] Barlett, C. P., \& Anderson, C. A. (2012). Direct and indirect relations between the Big 5 personality traits and aggressive behavior. Personality and Individual Differences, 52, 870-875. doi:10.1016/j.paid.2012.01.029

[5] Bernat, D.H., Oakes, J.M., Pettingell, S.L., \& Resnick, M. (2012). Risk and direct protective factors for youth violence: Results from the National Longitudinal Study of Adolescent Health. American Journal of Preventive Medicine, 43, 57-66. doi:10.1016/j.amepre.2012.04.023

[6] Bjorkqvist, K., Osterman, K., \& Kaukiainen, A. (1992). The development of direct and indirect aggressivc strategics in males and fcmales. In K. Bjorkqvist \& P. Niemela (Eds.), Of mice and women: Aspects of female aggression (pp. 51-64). San Diego, CA: Academic Press. doi:10.1017/s0730938400022528

[7] Bjorkqvist, K., Osterman, K., Oommen, T, K., \& Lagersprtz, K., M., J. (2001). Physical, verbal, and indirect aggression among Hindu, Muslim and Sikh Adolescents in India. In M. Martinez (Ed). Prevention and Control of Aggression and the impact on its victims. Netherlands, NE: Kluwer Academic Publisher. doi:10.1007/978-14757-6238-9_45

[8] Bjorkqvists, K., Lagerspertz, K, M., Kaukiainen, A. (1992). Do girls manipulate and boys fight? Developmental trends regarding direct and indirect aggression. Aggressive Behavior, 18, 117-127. doi:10.1002/1098-2337(1992)18:2\%3C117::aidab2480180205\%3E3.0.co;2-3

[9] Blum, J., Ireland, M., \& Blum, R.W. (2003). Adolescent Health. Gender differences in juvenile violence: A report from Add Health. Journal of Adolescent Health, 32, 234-240. doi:10.1016/s1054$139 \mathrm{x}(02) 00448-2$

[10] Borum, R., Bartel, P., \& Forth, A. (2005). Structured Assessment of Violence Risk in Youth (SAVRY). In T. Grisso, G. Vincent, \& D. Seagrave (Eds.), Mental health screening and assessment in juvenile justice (pp. 311-323). New York: Guilford Press. doi:10.4135/9781412959537.n302

[11] Bowlby, J. (1988). Attachment, communication, and the therapeutic process. In A secure base: Parent-child attachment and healthy human development (pp. 137-157). New York: Basic Books. doi:10.1176/ps.41.6.684-a

[12] Boynton-Jarrett, R., Ryan, L.M., Berkman, L.F., \& Wright, R.J. (2008). Cumulative violence exposure and self-rated health: longitudinal study of adolescents in the United States. Pediatrics, 122, 961-70. doi:10.1542/peds.2007-3063

[13] Bushman, B. J., \& Huesmann, L. R. (2010). Aggression. In S. T. Fiske, D. T. Gilbert, \& G. Lindzey (Eds.), Handbook of social psychology (pp. 833-863). New York, NY: John Wiley \& Sons. doi:10.1002/9780470561119.socpsy002023

[14] Buss, A. H., \& Perry, M. (1992). The Aggression Questionnaire. Journal of Personality and Social Psychology, 63(3), 452-459. doi:10.1037/0022-3514.63.3.452
[15] Carroll, A., Houghton, S., Hattie, J., \& Durkin, K. Y. (1999). Adolescent reputation enhancement: differentiating delinquent, nondelinquent, and at-risk youths. Journal of Child Psychology and Psychiatry, 40, 593-606. doi:10.1017/s0021963099003807

[16] Collins, A. M., \& Loftus, E. F. (1975). A spreading-activation theory of semantic processing. Psychological Review, 82, 407-428. doi:10.1037/0033-295x.82.6.407

[17] Compton, W. C., Smith, M.L. Cornish, K.A. and Qualls, D.L. (1996). Factor structure of mental health measures. Journal of Personality and Social Psychology, 71(2), 406-413. doi:10.1037/00223514.71.2.406

[18] Diener, E. (2000). Subjective well-being: The science of happiness, and a proposal for national index. American Psychologist, 55, 34-43. doi:10.1037/0003-066x.55.1.34

[19] Diener, E., Emmons, R. A., Larsen, R. J., \& Griffin, S. (1985). The Satisfaction with Life Scale. Journal of Personality Assessment, 49, 71-75. doi:10.1207/s15327752jpa4901_13

[20] Diener, E., Suh, E. M., Lucas, R. E., \& Smith, H. E. (1999). Subjective well-being: Three decades of progress. Psychological Bulletin, 125, 276-302. doi:10.1037/0033-2909.125.2.276

[21] Diener, E., Wirtz, D., Tov, W., Kim-Prieto, C., Choi, D., Oishi, S., \& Biswas-Diener, R. (2010). New measures of well-being: Flourishing and positive and negative feelings. Social Indicators Research, 39, 247-266. doi:10.1007/978-90-481-2354-4_12

[22] Diong, S.M., Bishop, G.D., Enkelmann, H.C., \& Khader, M. (2005). Anger, Stress, Coping, Social Support and Health: Modelling the relationships. Psychology and Health, 20(4), 467-495. doi:10.1080/0887044040512331333960

[23] Dollard, J., Doob, L., Miller, N., Mowrer, O., \& Sears, R. (1939). Frustration and Aggression. New Haven, CT: Yale University Press. doi:10.1037/10022-000

[24] Dutt, D., Pandey, G. K., Pal, D., Hazra, S., \& Dey, T. K. (2013). Magnitude, Types and Sex Differentials of Aggressive Behaviour among School Children in a Rural Area of West Bengal. Indian Journal of Community Medicine: Official Publication of Indian Association of Preventive \& Social Medicine, 38(2), 109-113. doi:10.4103/0970-0218.112447

[25] Emler, N. Y., \& Reicher, S. (2005). Delinquency: Cause or consequence of social exclusion? Abrams, E.D., Hogg, M.A., \& Marques, J.M.Y. (Eds.), The social psychology of inclusion and exclusion (pp. 211-241). New York: Psychology Press.

[26] Estévez, E., Moreno, D., Jiménez, T. Y., \& Musitu, G. (2013). From victim to aggressor: An analysis of the relationship between victimization and violent behavior at school. Spanish Journal of Psychology, 16, 1-13. doi:10.1017/sjp.2013.40

[27] Fang, X., \& Corso, P. (2007). Child maltreatment, youth violence, and intimate partner violence: A developmental trajectory. American Journal of Preventive Medicine, 33, 281-290. doi:10.1016/j.amepre.2007.06.003

[28] Frederickson, B. L. (2000, March 7). Cultivating positive emotions to optimize health and well-being. Prevention and Treatment, 3, Article 0001a. Retrieved May 8, 2001, from http://journals.apa.org/prevention/volume3/pre0030001a.html

[29] Glaser, D. (2000), Child Abuse and Neglect and the Brain-A Review. Journal of Child Psychology and Psychiatry, 41, 97-116. doi:10.1111/1469-7610.00551

[30] Haynie, D.L., Petts, R.J., Maimon, D., \& Piquero, A.R. (2009). Exposure to violence in adolescence and precocious role exits. Journal of Youth and Adolescence, 38(3), 269-86. doi:10.1007/s10964-008-9343-2

[31] Hill, S.Y., \& Muka, D. (1996). Childhood psychopathology in children from families of alcoholic female probands. Journal of the American Academy of Child and Adolescent Psychiatry, 35, 725-733. doi:10.1097/00004583-199606000-00012

[32] Huesmann, L.R. (1982). Information processing models of behavior. In: Hirschberg, N., Humphreys, L. (Eds.), Multivariate Applications in the Social Sciences (pp. 261-288). Hillsdale, NJ: Erlbaum.

[33] Hunter, W.M., Jain, D., Sadowski, L.S., \& Sanhueza, A.I. (2000). Risk factors for severe child discipline practices in rural India. Journal of Pediatric Psychology, 25, 435-447. doi:10.1093/jpepsy/25.6.435

[34] Jin, H. M., Park, B. S., \& Bae, S. W. (2011). The impact of informal labeling, self-esteem, depression, and aggression on juvenile 
delinquency: Focusing on path analysis. Journal of Adolescent Welfare, 13(2), 121-148.

[35] Kahneman, D. (1999) Objective Happiness. In Kahneman, D., Diener, E. \& Schwarz, N. (Eds.), Well-Being: The Foundations of Hedonic Psychology (pp.3-25). New York: Russell Sage Foundation.

[36] Kaplan, Y. (2017). School-Specific Subjective Wellbeing and Emotional Problems among High School Adolescents. Journal of Positive Psychology and Wellbeing, 1(1), 1-9. Retrieved from http://journalppw.com/index.php/JPPW/article/view/1

[37] Keyes, C. L. M. (2002). The mental health continuum: From languishing to flourishing in life. Journal of Health and Social Behavior, 43, 207-222. doi:10.2307/3090197

[38] Keyes, C. L. M. (2005). Mental illness and/or mental health? Investigating axioms of the complete state model of health. Journal of Consulting and Clinical Psychology, 73, 539-548. doi:10.1037/0022006x.73.3.539

[39] Kim, H. S., \& Lee, S. H. (2008). A study on the relations among anger expression mode, depression, and aggression in vocational high school students. Journal of Korean Academy of Community Health Nursing, 19(2), 270-279.

[40] Kim-Cohen, J., Caspi, A., Taylor, A., Williams, B., Newcombe, R., Craig, I. W., et al., (2006). MAOA, maltreatment, and geneenvironment interaction predicting children's mental health: New evidence and a meta-analysis. Molecular Psychiatry, 11, 903-913. doi:10.1038/sj.mp.4001851

[41] Krakowski, M. (2003). Violence and serotonin: influence of impulse control, affect regulation, and social functioning. Journal of Neuropsychiatry and Clinical Neurosciences, 15, 294- 305. doi:10.1176/appi.neuropsych.15.3.294

[42] Kumar, M., Bhilwar, M., Kapoor, R., Sharma, P., \& Parija, P. (2016). Prevalence of aggression among school going adolescents in India: A review study. Indian Journal of Youth and Adolescent Health, 3(4), $39-47$.

[43] Laub, J. H., \& Sampson, R.J. (1993). Turning Points in the Life Course: Why Change Matters to the Study of Crime. Criminology, 31, 301-325. doi:10.1111/j.1745-9125.1993.tb01132.x

[44] Lee, M. L., Gil, E. B., Yoo, B. R., \& Kim, J. H. (2012). Differences in early adolescents' affect states depending on level of depression across daily interpersonal contexts. Mirae Youth, 9(2), 61-78. doi:10.1016/j.anr.2014.05.007

[45] Lopez, V. A., \& Emmer, E. T. (2002). Influences of Beliefs and Values on Male Adolescents' Decision to Commit Violent Offenses. Psychology of Men and Masculinity, 3(1), 28-40. doi:10.1037/15249220.3.1.28

[46] Malamuth, N. M., \& Brown, L. M. (1994). Sexually aggressive men's perceptions of women's communications: Testing three explanations. Journal of Personality and Social Psychology, 67, 699-712. doi:10.1037//0022-3514.67.4.699

[47] Martin, I., Palepu, A., Wood, E., Li, K., Montaner, J., \& Kerr, T. (2009). Violence among street-involved youth: the role of methamphetamine. European Addiction Research, 15(1), 32-38. doi:10.1159/000173007

[48] Maxfield, M.G., \& Widom, C.S. (1996). The cycle of violence: Revisited six years later. Archives of Pediatric and Adolescent Medicine, 150, 300-395.

[49] McGuire, J. (2008). A review of effective interventions for reducing aggression and violence. Philosophical Transactions of the Royal Society B: Biological Sciences, 363(1503), 2577-2597. doi:10.1098/rstb.2008.0035

[50] Miller, N. E. (1941). The frustration-aggression hypothesis. Psychological Review, 48, 337-342. doi:10.1037/h0055861

[51] Miller, T. Q., Smith, T.W., Tumer, C.W., Guijarro, M. L., \& Halley, A. J. (1996). A meta-analytic review of research on hostility and physical health. Psychological Bulletin, 119, 322-348. doi:10.1037/0033-2909.119.2.322

[52] Mitrofan, N., \& Ciuluvica, C. (2012). Anger and hostility as indicators of emotion regulation and of the life satisfaction at the beginning and the ending period of the adolescence. Procedia Social and Behavioral Sciences, 33, 65-69. doi:10.1016/j.sbspro.2012.01.084

[53] Moffitt, T. E., Arseneault, L., Belsky, D., Dickson, N., Hancox, R. J., Harrington, H. L. et al., (2011). A gradient of childhood self-control predicts health, wealth, and public safety. Proceedings of the
National Academy of Sciences, 108, 2693-2698. doi:10.1073/pnas.1010076108

[54] Moreira, P. A. S., Cloninger, C. R., Dinis, L., Sá, L., Oliveira, J. T., Dias, A., \& Oliveira, J. (2014). Personality and well-being in adolescents. Frontiers in Psychology, 5, 1494. doi:10.3389/fpsyg.2014.01494

[55] Murlidhar, M., \& Shastri, S. (2016). Aggressive Behaviour among Elementary School Children in Bangalore: A Study on Gender and Grade Differences. International Journal of Indian Psychology, 3(4), 152-177. doi: 18.01.111/20160304

[56] Musante, L., \& Treiber, F.A. (2000). The relationship between angercoping styles and lifestyle behaviors in teenagers. Journal of Adolescent Health, 27, 63-68. doi:10.1016/s1054-139x(99)00098-1

[57] Owensa, L.D., \& MacMullina, C.E. (1995). Gender differences in aggression in children and adolescents in South Australian schools. International Journal of Adolescent and Youth, 6, 21-35. doi:10.1080/02673843.1995.9747776

[58] Patrick, C.J. (2008). Psychophysiological correlates of aggression and violence: an integrative review. Philosophical Transactions of The Royal Society, 363, 2543-2555. doi:10.1098/rstb.2008.0028

[59] Patterson, G., Littman, R. A., \& Bricker, W. (1967). Assertive behavior in children; a step toward a theory of aggression. Monograph of the Society for Research in Child Development, 32(5). doi:10.2307/1165737

[60] Pemberton, C.K., Neiderhiser, J.M., Leve, L.D., Natsuaki, M.N., Shaw, D.S., Reiss, D., et al., (2010). Influence of parental depressive symptoms on adopted toddler behaviors: An emerging developmental cascade of genetic and environmental effects. Development and Psychopathology, 22, 803-818. doi:10.1017/s09545794100004

[61] Penton-Voak, I. S., Thomas, J., Gage, S. H., McMurran, M., McDonald, S., \& Munafo, M. R. (2013). Increasing recognition of happiness in ambiguous facial expressions reduces anger and aggressive behavior. Psychological Science, 24(5), 688-697. doi:10.1177/0956797612459657

[62] Pérez Nieto, M.A., Camuñas, N., Cano-Vindel, A., Miguel-Tobal, J.J., \& Iruarrizaga, I. (2000). Anger and anger coping: A study of attributional styles. Studia Psychologica, 42, 289-302.

[63] Puskar, K., Bernardo, L., Haley, T., \& Hetager Stark, K. (2008). Anger correlated with psychosocial variables in rural youth. Issues in Comprehensive Pediatric Nursing, 31, 71-87. doi:10.1080/01460860802023513

[64] Reyna, C., Lello, M.G., Sánchez, A., \& Brussino, S. (2011). The Buss Perry Aggression Questionnaire: Construct validity and gender invariance among Argentinean adolescents. International Journal of Psychological Research, 4(2), 30-37. doi:10.21500/20112084.775

[65] Ryan, R. M., \& Deci, E. L. (2001). On happiness and human potentials: A review of research on hedonic and eudaimonic wellbeing. In S. Fiske (Ed), Annual review of psychology, 52, 141-166. Palo Alto, CA: Annual Reviews, Inc. doi:10.1146/annurev.psych.52.1.141

[66] Ryff, C. D., \& Keyes, C. L. M. (1995). The structure of psychological well-being revisited. Journal of Personality and Social Psychology, 69, 719-727. doi:10.1037/0022-3514.69.4.719

[67] Ryff, C. D., \& Singer, B. H. (1998). The contours of positive human health. Psychological Inquiry, 9, 1-28. doi:10.1207/s15327965pli0901_1

[68] Seligman, M. E. P. (2011). Flourish. New York, NY: Simon \& Schuster.

[69] Shaheen, S., \& Jahan, M. (2014). The Role of Optimism in experience of Student Stress and Suicidal Ideation. Journal of Humanities and Social Science, 19 (11), 23-34. doi:10.9790/0837191162334

[70] Sharma, M. K., \& Marimuthu, P. (2014). Prevalence and Psychosocial Factors of Aggression among Youth. Indian Journal of Psychological Medicine, 36(1), 48-53. doi:10.4103/02537176.127249

[71] Silvers J. A., McRae K., Gabrieli J. D. E., Gross J. J., Remy K. A., \& Ochsner K. N. (2012). Age-related differences in emotional reactivity, regulation, and rejection sensitivity in adolescence. Emotion, 12, 1235-1247. doi:10.1037/a0028297

[72] Simons-Morton, B. G., Hartos, J. L., \& Leaf, W. A. (2002). Promoting parental management of teen driving. Injury Prevention, 8(2), ii24-ii31. doi: 10.1136/ip.8.suppl_2.ii24 
[73] Sin, N. L., \& Lyubomirsky, S. (2009). Enhancing well-being and alleviating depressive symptoms with positive psychology interventions: A practice-friendly meta-analysis. Journal of Clinical Psychology: In Session, 65, 467-487. doi:10.1002/jclp.20593

[74] Singh, K. (2016). Psychological profile of University Boxers (Unpublished Doctoral Thesis). Panjab University, Chandigarh, India.

[75] Singh, K., Junnarkar, M., \& Kaur, J. (2016). Measures of positive psychology. India: Springer Nature. doi:10.1007/978-81-322-36313_1

[76] Smith, C., \& Thornberry, T. P. (1995). The relationship between childhood maltreatment and adolescent involvement in delinquency. Criminology, 33, 451-481. doi:10.1111/j.1745-9125.1995.tb01186.x

[77] Smith-Khuri, E., Iachan, R., Scheidt, P.C., Overpeck, M.D., Nic Gabhainn, S., Pickett, W., Harel, Y.A. \& the HBSC International Violence Study Group. (2004). A cross-national study of violencerelated behaviours in adolescents. Archives of Pediatric and Adolescent $\quad$ Medicine, $\quad$ 158(6), $539-44$. doi:10.1001/archpedi.158.6.539

[78] Steinberg, L. (1987). The impact of puberty on family relations. Effects of pubertal status and pubertal timing. Developmental Psychology, 23, 451-460. doi:10.1037/0012-1649.23.3.451

[79] Sterzer, P., \& Stadler, C. (2009). Neuroimaging of Aggressive and Violent Behaviour in Children and Adolescents. Frontiers in Behavioral Neuroscience, 3, 35. doi:10.3389/neuro.08.035.2009

[80] Swahn, M. H., Bossarte, R. M., Palmier, J. B., Yao, H., \& Van Dulmen, M. H. M. (2013). Psychosocial characteristics associated with frequent physical fighting: Findings from the 2009 National Youth Risk Behavior Survey. Injury Prevention, 19, 143-146. doi:10.1136/injuryprev-2012-040381

[81] Ttofi, M.M., Farrington, D.P., Lösel, F., \& Loeber, R. (2011). The predictive efficiency of school bullying versus later offending: A systematic/meta-analytic review of longitudinal studies. Criminal Behaviour and Mental Health, 21, 80-89. doi:10.1002/cbm.808

[82] Tweed, R. G., Bhatt, G., Dooley, S., Spindler, A., Douglas, K. S., \& Viljoen, J. L. (2011). Youth violence and positive psychology: Research potential through integration. Canadian Psychology/Psychologie canadienne, 52(2), 111-121. doi:10.1037/a0020695

[83] Valadez, I. (2008). Violencia escolar: maltrato entre iguales en escuelas secundarias de la zona metropolitana de Guadalajara. Informe de estudio. México: Colección Salud Materno Infantil. Guadalajara: Universidad de Guadalajara.

[84] Warburton, W. A., \& Anderson, C. A. (2015). Social psychology of aggression. In J. Wright \& J. Berry (Eds.), International Encyclopedia of Social and Behavioral Sciences, 373- 380. Oxford, England: Elsevier. doi:10.1016/b978-0-08-097086-8.24002-6

[85] Waterman, A. S. (1993). Two conceptions of happiness: Contrasts of personal expressiveness (eudaimonia) and hedonic enjoyment. Journal of Personality and Social Psychology, 64, 678-691. doi:10.1037/0022-3514.64.4.678

[86] Watson, D., Clark, L. A., \& Tellegan, A. (1988). Development and validation of brief measures of positive and negative affect: The PANAS scales. Journal of Personality and Social Psychology, 54(6), 1063-1070. doi:10.1037/0022-3514.54.6.1063

[87] World Health Organization. (2016, September 30). Youth Violence [Fact Sheet]. Retrieved from http://www.who.int/en/news-room/factsheets/detail/youth-violence.

[88] Yadav, G. (2010). Study of psychological well-being and gratitude of adolescents in relation to personality bonding and happiness of parents (Unpublished Doctoral Thesis). Panjab University, Chandigarh, India. 